\title{
Production Potential of Finger Millet (Eleusine coracana L. Gaertn) as Affected by Integrated Nutrient Management Practices: A Review
}

\author{
Ashok Kumar Roy ${ }^{1}$, Md. Naiyar Ali ${ }^{1}$ and Ritika Narayan ${ }^{2}$ \\ ${ }^{1}$ Department of Agronomy; Birsa Agricultural University, India \\ ${ }^{2}$ Department of Soil Science and Agricultural Chemistry; Birsa Agricultural University, India \\ *Corresponding author
}

Keywords

INM, FYM,

Azospirillum and Biofertilizers

Article Info

Accepted:

08 January 2020

Available Online:

10 February 2020

A B S T R A C T

This article comprises of the background information resulting from the previous work done by various scientists of India and Abroad on the effect of Integrated Nutrient Management (INM) on various growth and yield attributes of finger millet crop and its nutrient uptake rate by influencing the nutrient status in soil system. Sustainable agricultural productivity might be achieved through a wise and balanced use of fertilizers. Integrated nutrient management (INM) is a judicious use of organic and inorganic sources of nutrient to crop fields for sustaining and maintaining soil productivity. It is the only possible approach in enhancing the soil productivity through a balanced use of mineral fertilizers combined with organic and biological sources of plant nutrients. It plays a vital role in improving the stock of plant nutrients in soil by increasing the efficiency of plant nutrients, thus limiting losses to the environment. It optimizes the function of the soil biosphere and ultimately sustaining the physical, chemical and biological properties of the soil etc.

\section{Introduction}

Finger millet (Eleusine coracana) is an important small millet crop grown in India and has the pride of place in having highest productivity among millets. It is grown on an area of 1.19 million hectare in India with a total production of 1.98 million tonnes and productivity of $1661 \mathrm{~kg} \mathrm{ha}^{-1}$ (Anonymous, 2013). It is a nutritive food for different age groups. Straw makes valuable fodder for both draught and milch animals. The production and productivity of finger millet is low because of inefficient nutrient management, heavy weed infestation, incidence of blast disease etc.

Despite the continued development of new and improved modern varieties and greater use of chemical fertilizers, yield growth began 
to slow in the latter part of the 20th century (Gruhn et al., 2000). Continuous use of chemical fertilizers alone has some deleterious effects on physical, chemical and biological properties of soil which in turn reflects on yield levels and soil health. Concern has also grown in recent years that the use of fertilizers, particularly inorganic fertilizers, can lead to serious environmental consequences. On account of this, balanced use of organic and inorganic fertilizer along with biofertilizer is important not only for increasing growth and yield but also for sustaining soil health (Pullicinoa et al., 2009). However, since organic manure cannot meet the total nutrient needs of modern agriculture, since their availability is limited hence integrated use of nutrients from fertilizers and organic sources is highly essential in supplying the plant requirements and maintaining the soil health (Singh et al., 1997).

Use of biofertilizers such as biological nitrogen fixing and phosphate solubilizing micro-organisms is also gaining importance since bio- fertilizers are cost effective, ecofriendly and renewable source of plant nutrient to supplement chemical fertilizers. Integrating inorganic, organic and biofertilizers are essential in realizing the higher yield and reducing cost of production was reported by Shekhawat et al., (2005). The work of various research workers discussed below indicated that integrated nutrient management practice may play significant role to promote growth and productivity of finger millet in a sustainable basis as well as soil health.

\section{Growth parameters of finger millet as affected by INM}

The results of the experiment carried out by Kumar et al., (2003) at GKVK, Bangalore on red sandy loams indicated that application of
100 per cent NPK fertilizers in conjunction with compost @ 7.5 t/ha increased plant height significantly in finger millet compared to that of 50 per cent NPK fertilizers + compost @ 5 t/ha and individual applications of compost and NPK fertilizers, however it was on par with 75 per cent of NPK fertilizers +compost@7.5 t/ha.

Basavarajappa et al., (2003) observed that significant increase in plant height of foxtail millet with enriched FYM + Azospirillum @ $10 \mathrm{~kg} / \mathrm{ha}(86.35 \mathrm{~cm})$ over individual application of enriched FYM $(84.16 \mathrm{~cm})$ and glyricidia GLM $(81.93 \mathrm{~cm})$ in shallow Alfisols of Hanumanamathi, Dharwad.

Another field study was conducted by Rathore and Gautam (2003) at New Delhi on nutrient management in pearl millet with varying levels of nitrogen and phosphorus along with biofertilizers (Azotobacter + VAM) and they observed that higher number of tillers and other growth parameters was recorded with the application of $40 \mathrm{~kg} \mathrm{~N}+30$ $\mathrm{kg} \quad \mathrm{P}_{2} \mathrm{O}_{5} / \mathrm{ha}$ along with biofertilizers (Azotobacter + VAM).

Kumara et al., (2007) reported significantly higher dry matter of $44.3 \mathrm{~g} / \mathrm{plant}$ with conjunctive use of RDF (100:50:50 kg $\mathrm{NPK} / \mathrm{ha}+7.5$ t FYM/ha) followed by 37.3 $\mathrm{g} /$ plant of dry matter of finger millet with $100 \%$ RDF.

Neelam et al., (2009) conducted a study during kharif season at CCSHAU, Hisar on sandy loam soil and concluded that plant growth characteristics viz., plant height $(212.7 \mathrm{~cm})$, total number of tillers/plant (4.71), dry matter accumulation/plant (107.36 g) and leaf area/plant $(944.9 \mathrm{~cm} 2)$ at harvest were found maximum with $60 \mathrm{~kg} \mathrm{~N}+40 \mathrm{~kg}$ $\mathrm{P}_{2} \mathrm{O}_{5} / \mathrm{ha}$ but was at par with $40 \mathrm{~kg} \mathrm{~N} / \mathrm{ha}+30$ $\mathrm{kg} \mathrm{P}_{2} \mathrm{O}_{5} / \mathrm{ha}+$ Biomix (Azotobacter + Azospirillum + PSB). 
Giribabu et al., (2010) in a study conducted at Bapatla, observed that application of $100 \%$ RDF (60:30:20 kg NPK/ha) + FYM 3 t/ha significantly increased plant height $(93.9 \mathrm{~cm})$ of finger millet over 75\% RDF + FYM 3 t/ha $(88.8 \mathrm{~cm})$, over individual application of FYM $(84.3 \mathrm{~cm})$ and $100 \%$ RDF $(88.5 \mathrm{~cm})$.

Saravanane et al., (2011) found that dry matter and LAI of finger millet increased with application of 100\% $\mathrm{N}$ as FYM (125:100:125 $\mathrm{kg} \mathrm{NPK} / \mathrm{ha}$ ) to the preceding potato crop which was on par with integration $50 \% \mathrm{~N}$ as Lantana (54.42 g/plant) and Parthenium spp. (52.76 g/plant) each with $50 \% \mathrm{~N}$ as inorganic individually in Indaf 9 variety of finger millet.

Yield and yield attributes of finger millet as affected by INM

Ramamoorthy and Lourduraj (2002) stated that application of $50 \% \mathrm{RDF}+50 \% \mathrm{FYM}+$ biofertilizer inoculation of Azospirillum and Aspergillus@ $25 \mathrm{~g} / \mathrm{kg}$ seed was found on par with biofertilizer + 100\% RDF (60:30:30 kg $\mathrm{NPK} / \mathrm{ha}$ ) regarding finger length of 11.5 and $10.8 \mathrm{~cm}$ in finger millet respectively.

Significantly higher finger length of 15.84 $\mathrm{cm}$, grain weight/panicle $(4.84 \mathrm{~g})$ of foxtail millet was found with application of enriched FYM + Azospirillum followed by glyricidia GLM $(14.12 \mathrm{~cm})$, enriched FYM $(13.60 \mathrm{~cm})$ and control $(11.89 \mathrm{~cm})$. Harvest index was found non-significant with enriched FYM + Azospirillum, enriched FYM, glyricidia GLM respectively (Basavarajappa et al., 2003).

Sapthagiri variety of finger millet grown on sandy loams of Tirupati produced on par fingers/earhead of 9.90, 9.71 and 9.58 and grain weight/ear of $6.19,6.16$ and $6.12 \mathrm{~g}$ with $100 \% \mathrm{RDF}, 75 \% \mathrm{RDF}+25 \% \mathrm{~N}$ through FYM and $75 \%$ RDF $+25 \% \mathrm{~N}$ through glyricidia GLM respectively (Sunitha et al., 2004).
Patil et al., (2006) studied various nutrient management systems at College of Agriculture, Phule found that application of $50 \% \mathrm{RDF}\left(50 \mathrm{~kg} \mathrm{~N} / \mathrm{ha}+25 \mathrm{~kg} \mathrm{P}_{2} \mathrm{O}_{5} / \mathrm{ha}\right)+$ FYM @ 2.5 t/ha + biofertilizer as seed treatment was significant in increasing the grain $(20.11 \mathrm{q} / \mathrm{ha})$ and fodder yield (28.17 $\mathrm{q} / \mathrm{ha}$ ) in finger millet.

Conjunctive use of RDF (100:50:50 kg N, $\left.\mathrm{P}_{2} \mathrm{O}_{5}, \mathrm{~K}_{2} \mathrm{O} / \mathrm{ha}\right)+7.5 \mathrm{t} \mathrm{FYM} / \mathrm{ha}$ improved the 1000 grain weight $(2.83 \mathrm{~g})$ over $100 \% \mathrm{RDF}$ alone $(2.62 \mathrm{~g})$ in finger millet (Kumara et al., 2007).

The PSB and plant growth promoting rhizobacteria (PGPR) together reduce $P$ fertilizer application by 50 per cent without any significant reduction of crop yield (Jilani et al., 2007)

Tyagi and Ramamoorthy (2007) investigated that there was increase in number of fingers/ear (6.93), increased test weight with application of $12.5 \mathrm{t} \mathrm{FYM/ha} \mathrm{in} \mathrm{finger} \mathrm{millet}$ + pigeon pea in 6:2 ratio which was on par with application of 40:20:20 kg NPK/ha (6.80) and FYM @ 12 t FYM/ha (6.60) individually in finger millet alone on clay loams.

Integrated use of RDF (100:50:50 kg N, $\mathrm{P}_{2} \mathrm{O}_{5}$, $\left.\mathrm{K}_{2} \mathrm{O} / \mathrm{ha}\right)+7.5 \mathrm{t}$ FYM/ha significantly improved the finger length by 10.5 per cent and maximum number of fingers/earhead (5.1) over 100 per cent RDF alone in HR 911 variety in finger millet (Kumara et al., 2007).

Significantly higher grain yield of 2038 and $2127 \mathrm{~kg} / \mathrm{ha}$ and straw yield of 3191 and 3016 $\mathrm{kg} / \mathrm{ha}$ was resulted from $50 \% \mathrm{~N}$ through FYM $+50 \%$ RDF and $50 \% \quad \mathrm{~N}$ through vermicompost $+50 \% \mathrm{RDF}$ respectively in GPU-28 variety of finger millet (Basavaraju and Purushotham, 2009). 
Among four levels of nutrient management systems tried the application of $100 \% \mathrm{RDF}$ $(60: 30: 20 \mathrm{~kg}$ NPK/ha) + $3 \mathrm{t}$ FYM/ha produced on par fingers/earhead in finger millet. Significantly increased the productive tillers/m2 (178.9) over $75 \%$ RDF $+3 \mathrm{t}$ FYM/ha (167.5) over individual application of $100 \%$ RDF (163.5) and FYM (155.5) in finger millet (Giribabu et al., 2010).

Jagathjothi et al., (2010) reported higher number of productive tillers/m2 (176), increased finger length of 7.15 and $7.01 \mathrm{~cm}$ with band placement of $2 \mathrm{t}$ enriched FYM/ha $+64: 55.5 \mathrm{~kg} \mathrm{NK} / \mathrm{ha}$ in CO14 variety of finger millet compared to other combinations of inorganic with organic nitrogen sources. Increased straw yields of 5908 and 5706 $\mathrm{kg} / \mathrm{ha}$ in finger millet was recorded with band placement of $2 \mathrm{t}$ enriched FYM/ha $+64: 55.5$ $\mathrm{kg} \mathrm{NK} / \mathrm{ha}$ and broadcasting with $4 \mathrm{t}$ enriched FYM/ha + 64:55.5 kg NK/ha over other treatments.

\section{Nutrient uptake of finger millet as affected by INM}

Nitrogen fixation is the prime mechanism of action suggested for the enhancement of plant growth by Azospirillum. Incorporation of atmospheric nitrogen into the host plant by Azospirillum was evaluated mainly by the indirect assay i.e., acetylene reduction (Dobereiner, 1977). Nitrogen fixation by Azospirillum has been confirmed by several workers, using not only conventional micro Kjeldhal assay but also by the more definite method of isotopic enrichment involving 15 N2 (Wong and Sternberg, 1979).

Several experiments conducted on sorghum, pearl millet, finger millet and rice at different locations in India under All India Coordinated Research Project on Biological Nitrogen Fixation have indicated the positive response of the cultivars to Azospirillum inoculation (SubbaRao, 1981).
Kalibhavi et al., (2003) reported that application of FYM (5 t/ha) + vermicompost (1.5 t/ha) + Azospirillum brasilence as soil application $(10 \mathrm{~kg} / \mathrm{ha})+100 \%$ recommended dose of fertilizers significantly increased $\mathrm{N}$ (254.49 kg/ha), P (27.07 kg/ha) and K (165.70 $\mathrm{kg} / \mathrm{ha}$ ) uptake in sorghum as compared to their individual application.

Significant increase in NPK uptake by grain as well as straw in finger millet was observed with combined application of $100 \%$ NPK fertilizer and $7.5 \mathrm{t}$ compost/ha over individual applications of organic and inorganic fertilizers on sandy loam soils of Bangalore (Kumar et al., 2003).

Raman and Krishnaprabu (2004) reported that in finger millet NPK uptake was significantly increased with application of $100 \%$ recommended NPK fertilizers in conjunction with FYM @ 12.5 t/ha over 100\% recommended NPK fertilizers alone.

Duryodhana et al., (2004) observed that the significant improvement in NPK uptake by grain and straw in finger millet was with application of $100 \%$ NPK fertilizers in conjunction with $7.5 \mathrm{t} / \mathrm{ha}$ compared to that of individual application of organic and inorganic fertilizers on sandy loam soils of Bangalore.

Meena and Gautam (2005) studied the effect of chemical fertilizers and biofertilizers on pearl millet which indicated that combined application of Azospirillum + PSB with $20 \mathrm{~kg}$ $\mathrm{N} / \mathrm{ha}+15 \mathrm{~kg} \mathrm{P}_{2} \mathrm{O}_{5} /$ ha recorded the highest $\mathrm{N}$, $\mathrm{P}$ and $\mathrm{K}$ uptake and was at par with $40 \mathrm{~kg}$

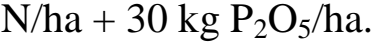

Rathore et al., (2006) recorded higher uptake of nitrogen and phosphorus by pearl millet with the application of $50 \%$ RDF + Azospirillum + PSB in comparison to $50 \%$ $\mathrm{RDF}, 50 \% \mathrm{RDF}+$ Azospirillum and $50 \%$ $\mathrm{RDF}+\mathrm{PSB}$. 
Choudhary and Gautam (2007) conducted a field experiment at IARI, New Delhi on pearl millet and reported that application of $60 \mathrm{~kg}$ nitrogen $+40 \mathrm{~kg}$ phosphorus/ha along with 10 t FYM/ha and biofertilizers gave significantly higher $\mathrm{N}$ and $\mathrm{P}$ uptake over control and FYM (5 and $10 \mathrm{t} / \mathrm{ha})+$ biofertilizers

\section{Economics of finger millet as affected by INM}

Purushotham et al., (1994) conducted field trial during kharif, finger millet cultivar Indaf $\mathrm{B}$ was given $0-90 \mathrm{~kg} \mathrm{~N}+0-60 \mathrm{~kg} \mathrm{P}+0-50 \mathrm{~kg}$ $\mathrm{K} / \mathrm{ha}$ in various combinations and $25 \mathrm{~kg}$ $\mathrm{ZnSO}_{4}$ with $90 \mathrm{~kg} \mathrm{~N}+60 \mathrm{~kg} \mathrm{P}+50 \mathrm{~kg} \mathrm{~K}+$ $\mathrm{ZnSO}_{4}$. Application of $60 \mathrm{~kg} \mathrm{~N} / \mathrm{ha}+60 \mathrm{~kg}$ $\mathrm{P} / \mathrm{ha}+30 \mathrm{~kg} \mathrm{~K} / \mathrm{ha}$ gave the highest benefit: cost ratio.

In a study on nutrient management systems, Rathore et al., (2005) observed that gross returns (₹ 35,661/ha), cost of cultivation (₹ 10,933/ha) and net return (₹ 24,728/ha) was highest with 125 per cent RD N, whereas benefit: cost ratio (2.26) for 125 per cent RD $\mathrm{N}$ was at par with 100 per cent RDN + biofertilizer.

Patil et al., (2006) studied various nutrient management systems at College of Agriculture, Phule and concluded that application of 50\% RDF + FYM @ 2.5 t/ha + biofertilizer as seed treatment was significant in increasing the gross monetary return (12,911.10/ha) over the others. The net monetary return (₹ 8867.75/ha) and B:C ratio (3.14) was also highest with this treatment.

Kumar et al., (2006) conducted an field trial on pearl millet at Hisar and reported that use of biofertilizers and biomix with 75 and 100 per cent $\mathrm{RD} \mathrm{N}$ improved the economics of system in terms of gross return, net return and benefit: cost ratio over absolute control, 75 and 100 per cent RD N.
Sonawane et al., (2007) observed that among various fertilizer levels, $60 \mathrm{~kg} \mathrm{~N} / \mathrm{ha}+40 \mathrm{~kg}$ $\mathrm{P}_{2} \mathrm{O}_{5} /$ ha recorded highest net return (₹ 17,740/ha) over other treatments and being at par with $40 \mathrm{~kg} \mathrm{~N} / \mathrm{ha}+30 \mathrm{~kg} \mathrm{P}_{2} \mathrm{O}_{5} / \mathrm{ha}+$ biofertilizers (₹ 17,599/ha). The benefit: cost ratio was highest with $40 \mathrm{~kg} \mathrm{~N}+30 \mathrm{~kg}$ $\mathrm{P}_{2} \mathrm{O}_{5} /$ ha + biofertilizers (2.38).

In conclusion, these reviews clearly suggest that integrating inorganic, organic and biofertilizers are essential in realizing the higher growth, yield and yield attributes of finger millet and reducing cost of cultivation by practicing integrated manner. The practices not only improve yield but also improves the soil physical, chemical, biological properties and nutrient availability.

\section{References}

Basavarajappa, R., Prabhakar, A.S and Halikatti, S.I. 2003. Effect of tillage, organics, nitrogen levels on growth components, drymatter accumulation and physiological parameters in foxtail millet (Setaria italica). Indian Journal of Agronomy 48(2): 111-113.

Basavarajappa, R., Prabhakar, A.S and Halikatti, S.I. 2003. Effect of tillage, organics, nitrogen levels on growth components, drymatter accumulation and physiological parameters in foxtail millet (Setaria italica). Indian Journal of Agronomy 48(2): 111-113.

Basavaraju, T.B and Purushotham, S. 2009. Integrated nutrient management in rainfed ragi (Eleusine coracana L. Gaertn.). Mysore Journal of Agricultural Sciences 43(2): 366-368.

Choudhary, R.S and Gautam, R.C. 2007. Effect of nutrient management practices on growth and yield of pearl millet (Pennisetum glaucum L.). Indian Journal of Agronomy 52(1): 64-66.

Dobereiner, J., 1977. Physiological aspects of nitrogen fixation in grass bacteria association. In: Recent developments in nitrogen fixation, Ed. Newton, W. E., 
Postagate, J.R. and Rodriguez-Barrueco, C. Academic Press, London pp.513-522.

Duryodhana, D., Gowda, G.K.T., Kadalli, G.G and Ashok, E.G. 2004. Uptake pattern of major nutrients at different growth stages by dryland finger millet (Eleusine coracana L. Gaertn.) from different sources and levels of nutrients. Mysore Journal of Agricultural Sciences 38(4): 487-495.

Giribabu, B., Lather, M.M., Chandra Sekhar, K and Sankara Rao, V. 2010. Effect of nutrient management system on productivity of finger millet (Eleusine coracana L. Gaertn.) cultivars under sandy soils. The Andhra Agricultural Journal 57(1): 4-6.

Giribabu, B., Lather, M.M., Chandra Sekhar, K and Sankara Rao, V. 2010. Effect of nutrient management system on productivity of finger millet (Eleusine coracana L. Gaertn.) cultivars under sandy soils. The Andhra Agricultural Journal 57(1): 4-6.

Gruhn P, Golleti F, Yudelman M (2000). Integrated Nutrient Management, Soil Fertility and Sustainable Agriculture: Current Issues and Future Challenges. Washington D.C. International Food Policy Research Institute. Food, Agriculture and Environment Discussion Paper 32.

Jagathjothi, N., Ramamoorthy, K. and Priya, R.S. 2010. Influence of enriched FYM with inorganic fertilizers on nutrient uptake, available nutrients and productivity of rainfed finger millet. Madras Agricultural Journal 87(10-12): 385-387.

Jilani, G., Akram, A., Ali, R.M., Hafeez, F.Y., Shamsi, I.H., Chaudhry, A.N. and Chaudhry, A.G. 2007. Enhancing crop growth, nutrients availability, economics and beneficial rhizosphere microflora through organic and biofertilizers. Annals of Microbiology 57: 177-183.

Kalibhavi, C., Kachapur, M.D. and Patil, R.H. 2003. Studies on integrated nutrient management in rabi sorghum. Journal of Maharashtra Agricultural Universities 28(1): 104-105.

Kumar, B.H., Sharappa, A., Krishnegowda, K.T. and Sudhir, K. 2003. Growth, yield and nutrient uptake as influenced by integrated nutrient management in dryland finger millet (Eleusine coracana L. Gaertn.). Mysore Journal of Agricultural Sciences 37(1): 24-28.

Kumar, P., Singh, H., Hooda, R.S and Singh, V.P. 2006. Effect of nitrogen levels and biofertilizers on yield and quality of crops in pearl millet-wheat cropping system. Haryana Journal of Agronomy 50(1): 7173.

Kumara, O., Naik, B.T. and Palaiah, P. 2007. Effect of weed management practices and fertility levels on growth and parameters in finger millet. Karnataka Journal of Agricultural Sciences 20(2): 230-233.

Kumara, O., Naik, B.T. and Palaiah, P. 2007. Effect of weed management practices and fertility levels on growth and parameters in finger millet. Karnataka Journal of Agricultural Sciences 20(2): 230-233

Meena, R. and Gautam, R.C. 2005. Effect of integrated nutrient management on productivity, nutrient uptake and moistureuse functions of pearl millet (Pennisetum glaucum). Indian Journal of Agronomy 50(4): 305-307.

Neelam, A., Kumar, A. and Singh V.P. 2009. Effect of fertilizer application in conjunction with biofertililizers on growth and yield of pearl millet under rainfed condition. Forage Research 35(2): 121123.

Patil, E.N., Chaudhari, P.M., Pawar, P.P. and Patil, H.E. 2006. Integrated moisture conservation technique and nutrient management systems for pearl millet [Pennisetum glaucum (L.) R. Br.] in semiarid conditions. Indian Journal of Dryland Agricultural Research \& Development 21(1): 85-87.

Patil, E.N., Chaudhari, P.M., Pawar, P.P. and Patil, H.E. 2006. Integrated moisture conservation technique and nutrient management systems for pearl millet [Pennisetum glaucum (L.) R. Br.] in semiarid conditions. Indian Journal of Dryland Agricultural Research \& Development 21(1): 85-87.

Pullicinoa, D.S., L. Massaccesia, L. Dixonb, R. Bolb and G. Gigliottia, 2009. Organic matter dynamics in a compost-amended 
anthropogenic landfill capping-soil. Europian Journal of Soil Sciences 61: 3547.

Purushotham, S., Hosmani, M.M. and Sharma, K.M.S. 1994. Response of finger millet to fertilizer application under rainfaid conditionsd. Karnataka Journal of Agriculture Sciences 7(1): 72-73.

Ramamoorthy, K., Lourduraj, A.C., Alaguduraj, S and Kandasamy, O.S. 2004. Effect of crop residue management of early season legumes on the succeeding rainfed finger millet. Madras Agricultural Journal 91(46): $180-183$.

Raman, R. and Krishnaprabu, S. 2004. Effect of integrated nutrient management on nutrient uptake and yield of finger millet. Journal of Ecobiology 16(3): 197-200.

Rathore, B.S., Singh, V.P and Hooda, R.S. 2005. Inoculation of pearl millet seed with mixed biofertilizer for nitrogen economy. Haryana Journal of Agronomy 21(1): 84-85.

Rathore, S.S. and Gautam, R.C. 2003. Response of direct seeded and transplanted pearl millet (Pennisetum glaucum L.) to nitrogen, phosphorus and biofertilizers in intercropping system. Indian Journal of Agronomy 48(3): 153-155.

Rathore, V.S., Singh, P. and Gautam, R.C. 2006. Productivity and water use efficiency of rainfed pearl millet (Pennisetum glaucum L.) as influenced by planting pattern and integrated nutrient management. Indian Journal of Agronomy 51(1): 46-48.

Saravanane, P., Nanjappa, H.V., Ramachandrappa, B.K and Soumya, T.M. 2011. Effect of residual fertility of preceding potato crop on yield and nutrient uptake of finger millet. Karnataka Journal of Agricultural Sciences 24(2): 234-236.

Shekhawat, K., Pahuja, S.S. and Singh, K.P. 2005. Nitrogen budgeting in wheat as influenced by integrated nutrient management. Haryana Journal of Agronomy 21: 210.

Singh, O.P. and Panwar, J.D.S. 1997. Effect of nitrogen fixing and phosphorus solubilising bacteria on nutrient uptake and yield of pearl millet. Indian Journal of Plant Physiology 2: 211-213.

Sonawane, P.D., Rodge, R.G. and Attarde, D.R. 2007. Effect of fertilizer, biofertilizer, intercropping system on pearl millet under rainfed conditions. Journal of Maharashtra Agricultural Universities 32(2): 176-178

Subba Rao, N.S. 1981. Response of crops to Azospirillum inoculation in India. In: Associative Nitrogen Fixation, Vol.I. Ed. Vose, P. B. and Ruschel, A. P. CRC Press, Baco Raton, Florida, pp.137-144.

Sunitha, N., Ravi, V. and Reddy, R. 2004. Nitrogen economy in finger millet through conjunctive use of organic manures and bio-fertilizers. Indian Journal of Dryland Agricultural Research and Development 19(2): 172-174.

Tyagi, S.K. and Ramamoorthy, K. 2007. Effect of organic fertilizers on yield and yield attributing traits of direct sown rainfed finger millet (Eleusine coracana Gaertn.). Annals Agricultural Research New Series 28(2): 156-159.

Wong, P.P. and Stenberg, M. E. 1979. Characterization of Azospirillum isolated from nitrogen fixing roots of harvested sorghum plants. Application Environmental Microbiology 38: 1189-1191.

\section{How to cite this article:}

Ashok Kumar Roy, Md. Naiyar Ali and Ritika Narayan. 2020. Production Potential of Finger Millet (Eleusine coracana L. Gaertn) as Affected by Integrated Nutrient Management Practices: A Review. Int.J.Curr.Microbiol.App.Sci. 9(02): 1242-1248.

doi: https://doi.org/10.20546/ijcmas.2020.902.147 